\title{
関節力覚制御アームによる衛星捕獲*1
}

\section{Capturing of Spacecraft by a Joint Impedance Controlled Robot Arm}

\author{
西田 信一郎*2 ·吉川 恒 夫*3
}

Shin-ichiro NishidA and Tsuneo YoshIKAwA

Key Words : Space Robot, Capture, Space Debris, Force Control, Simulation

\begin{abstract}
Since attitude control is not working, most space debris is rotating. For this reason, in capture of the space debris, there is a complicated dynamic interaction among a target, a servicing vehicle, and its robot arm, and there is a possibility that big load may occur. This paper proposes a new capture strategy of the space debris that utilizes joint impedance control and joint virtual depth control to the arm for capture. The validity of the proposed strategy is verified by some simulations and experiments.
\end{abstract}

\section{1. は じめ に}

故障した人工衛星あるいは寿命の尽きた人工衛星 (機能 不全衛星) か軌道上に放置されたスペースデブリ (宇宙ゴ ミ) の増加か問題となっている．このため，有人宇宙機や 稼動している人工衛星がスペースデブリや光の破片と衝突 して致命的なダメージを受ける危険性が年々高まっている そこで，筆者らはスペースデブリの回収/除去や修理によ る再利用の研究を行っている ${ }^{1,2)}$. スペースデブリの回収や 修理に必須かつ重要なタスクとして捕獲作業が挙げられる。 スペースデブリでは, 姿勢制御系が機能しておらず, 機能不 全に陥ったときの残留角運動量などのために回転運動して いるのが一般的である . 回転が高速の場合には , 外力を与 えて回転速度を低減する必要があるが残留回転が残る。ま た , 大半のスペースデブリは回転速度が低い. 弚こで, この ような低速回転の対象の捕獲を作業機に搭載されたロボッ トアームによって実施することを検討する．

視覚用マークや捕獲用ハンドルを有するような協力的な 対象衛星のロボットアームによる捕獲については, ETS-VII において成功裏に軌道上実験が実施された ${ }^{3,4)}$. しかし，ス ペースデブリは, 回収されることを当初より想定していな いため，これらの捕獲を容易にする機器を持たない非協力 なターゲットである．また，上記のように低速回転してい る場合が多いが, 关の質量特性を事前に完全に把握するこ とは困難である．また，宇宙機には太陽電池パドルなどの 柔軟付属物が付いている場合が多い．このため，捕獲/制 動時に追従誤差や相互の宇宙機の動的挙動による荷重が発 生するが, 弚の緩和か課題である.また, ロボットアーム から制動力を印加して回転速度を一致させる必要がある .

\footnotetext{
*1 C) 2005 日本航空宇宙学会

平成 16 年 5 月 10 日原稿受理

*2 宇宙航空研究開発機構

*3 京都大学大学院
}

ETS-VII では, アームの手首部に設けた 6 軸力/トルクセ ンサによる仮想コンプライアンス制御により捕獲時の荷重 緩衝が行われた ${ }^{4)}$.しかし，このような方式ではセンサとア クチュエータの間に柔軟構造が介在し, 制御帯域を十分に 高くできず, 運動している非協力ターゲットの捕獲には適 用が難しい，捕獲/制動時の荷重の緩和方法として関節にア クティブコンプライアンスを持たせる方式がある5) が , 各 関節にトルクセンサを組込む必要があり, 光れによる構成 の複雑化や剛性低下か課題となっていた .

そこで, 筆者らは, シンプルな構成で高剛性・高耐荷重 なトルクセンサを組込んだ関節の試作・研究を行っており， 弚の開発について一応の目処を得ている6,7).

関節部のトルク検出を用いた衛星捕獲については, 小松 らの研究 ${ }^{8)}$ があるが, 関節角度制御による動作を基本とし， 捕獲時の荷重緩衝はアームブームの弾性に依存し, 生じた 振動をトルク制御により減衰する方式であり, 運動対象に 積極的に制動力を加える方式ではない．

本稿では, 上記のような回転運動している質量特性が十 分に把握できていない非協力的なターゲット衛星のロボッ トアームによる捕獲作業に対し, 捕獲/制動時の動的な荷重 を緩衝すると同時に制動力を印加する制御方式として, 関 節仮想インピーダンス制御をベースとした仮想食い込み量 の目標值制御である関節仮想デプス制御を提案する．また， 動力学シミュレーション解析と 2 次元アーム実験により光 の有効性を確認した結果につき報告する．

\section{2. 捕獲対象と作業条件}

2.1 想定対象 NORAD などのデータから, 高度 500 $1500 \mathrm{~km}$ の太陽同期軌道には, 軌道高度 ・軌道傾斜 角が近い軌道に複数の物体や衛星が地球周回飛行している ケースが散見される.これらは, 過去に地球観測という共 通の目的で衛星の最適な軌道が選定された結果と推測され る、逆にこのような軌道は, 有用な軌道であり, スペース 
第 1 表 捕獲対象衛星のモデル

\begin{tabular}{ll|ll}
\hline Items & \multicolumn{1}{c|}{ Value } & Items & Value \\
\hline Mass & $4000 \mathrm{~kg}$ & Body size & $2 \mathrm{~m} \times 2 \mathrm{~m} \times 4 \mathrm{~m}$ \\
Inertia & $I_{x x}: 52200 \mathrm{kgm}^{2}$ & Wheel & $50 \mathrm{Nms}$ \\
& $I_{y y}: 14400 \mathrm{kgm}^{2}$ & momentum & \\
& $I_{z z}: 56700 \mathrm{kgm}^{2}$ & capacity & \\
\hline
\end{tabular}

デブリの回収・投棄か特に有効な軌道であると考えられる 軌道高度や軌道傾斜角の近い軌道間の移動は, 所要マヌー バ量が比較的少ないため, 1 機の軌道上作業機で軌道間を 順次移動して複数のスペースデブリを回収・投棄する研究 が進められている．本稿では，このような低軌道衛星の回 収を対象として想定する．ロケットは，太陽同期低軌道へ 4 トン程度の衛星を打ち上げる能力が確保されている例が 多い(例えば，H-IIA ロケットの太陽同期低軌道への衛星 打上能力は最大で 4 トン強). 弚こで, 捕獲対象衛星とし て，第 1 表に示すターゲットモデルを想定/設定した .こ こでは, 衛星重量は体積に比例するものとした . 以下では， このターゲットモデルを前提として検討を進める．

2.2 対象の姿勢と回転 地球を周回するスペースデブ リの多くが, 故障あるいは寿命の尽きた人工衛星である このような機能不全衛星の大半は, 姿勢制御系が機能して おらず, 衛星姿勢か地球指向や慣性指向に維持されていな い. 人工衛星において姿勢制御系か機能しなくなったとき には, 少なくとも搭載されているホイールの残留角運動量 が衛星の残留角運動量となり, 衛星は回転した状態となる。 容量 $50 \mathrm{Nms}$ のホイールに最大の角運動量が蓄積していた と仮定すると, 回転が最大慣性主軸 ( $z$ 軸) 回りに収斂し た後のターゲットモデルの回転速度は, 約 $0.05 \mathrm{deg} / \mathrm{s}$ と なる

2.3 捕獲部位 捕獲対象部位としては，掴みやすい部位 として, ロケットの衛星との結合部 (PAF:Payload Attach Fitting) とのインタフェース構造や太陽電池パドルブーム の付け根部 , ハイゲインアンテナマストなどのブーム状で 掴みやすい部位を想定する．なお，捕獲部位が柔軟性を有 する場合は, 光の弾性により捕獲時の荷重の変動速度が減 少し, 荷重の緩和が容易になる1) 傾向があるが, 過剩に柔 軟な場合には制動力の方向制御が難しくなる.本論文では， 一般性の確保のため，高剛性部位の捕獲を前提とする．

\section{3. 捕獲作業戦略}

3.1 接近作業の戦略 スペースデブリは, 先に述べた ように回転運動している場合が多い，また，故障や年月の 経過による損傷により運用時から形状が変化していること が考えられる．弚こで，次の接近作業戦略を採る。

(1) ターゲットと同一軌道上の近傍でターゲットの外形の観 察および姿勢・運動の計測を行う.

(2) ターゲットの回転速度が大きいときには, 捕獲の前に何 らかの手段による回転速度低減を行う。

即ち, ターゲットの回転によって衝突が生じない距離で作 業機の相対的な位置保持飛行を行い, ターゲットの運動を

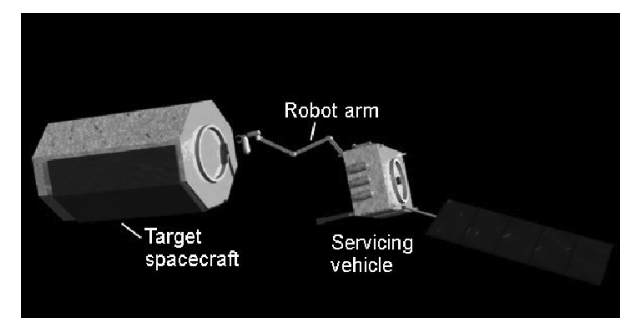

第 1 図＼cjkstart作業機ロボットによるデブリ捕獲の概念図

計測する．弚の結果，ターゲットが高速で回転している場 合には，衝撃スラスト法9)などによる回転速度低減を行う． ターゲットの回転速度が捕獲部位が手前側にある間に回転 を減速できる程度に低速（第 1 表のターゲットを $20 \mathrm{~N}$ の 制動力で減速する場合，約 $0.04 \mathrm{rad} / \mathrm{s}$ 以下) であれば，作 業機の 6 以上の自由度を有するロボットアームを用いて捕 獲部位を追従することにより，捕獲機構と捕獲部位の相対 速度を下げた状態て捕獲することができる．対象への接近 後のロボットアームによるターゲット捕獲の概念図を第 1 図に示す。

3.2 アームによる捕獲の戦略 対象に接近した後の口 ボットアームによるターゲット捕獲では，以下の戦略を採る (1) 近傍からのターゲット運動計測により，捕獲部位が作業 機正面側に回ってくるタイミングと相対運動を予測して， これに同期する運動をしながら捕獲部位を画像処理/画像 フィードバック制御により追従して捕獲を行う.

(2) 捕獲時の速度差/位置ずれによる衝撃は, 高い応答性の 関節コンプライアンス制御を基本としたアーム関節力覚 制御により緩和する。

(3) アーム先端部質量による捕獲衝撃の高周波成分は, アー ム制御では緩和しきれないため捕獲機構部の適切な弾性 部材により緩和する.

(4) 把持後は, 減速プロファイルに沿ったアーム動作と力覚 制御による制動力印加を行い, 弚れによりターゲットの残 留運動量および角運動量の一部の作業機への移譲を行う . (5)一旦，作業機とターゲットが一体で共通の質量中心回り に回転する状態とし, 兴の後, 作業機のスラスタ等の姿 勢制御アクチュエータにより回転運動を減速する。 このため, ロボットアームには画像フィードバック機能と 関節力覚制御機能が必要となる。光こで, 捕獲作業時の口 ボットアームの制御ブロック図は, 第 2 図に示す構成とす る. 捕獲時の作業機の姿勢制御は, スラスタの無駄噴き防 止のためにオフする .

\section{4. 関節力覚制御}

4.1 力覚センサの配置 ロボットアームの力覚制御に使 用する力覚センサの配置として，次の 2 方式が考えられる . a. アーム手先部に 6 軸力/トルクセンサを設ける .

b. 各関節部にトルクセンサを設ける .

宇宙用ロボットアームは, 重力の影響が小さいため, 華奢な 構成のままでのアーム長大化が容易であり，大質量物を扱 


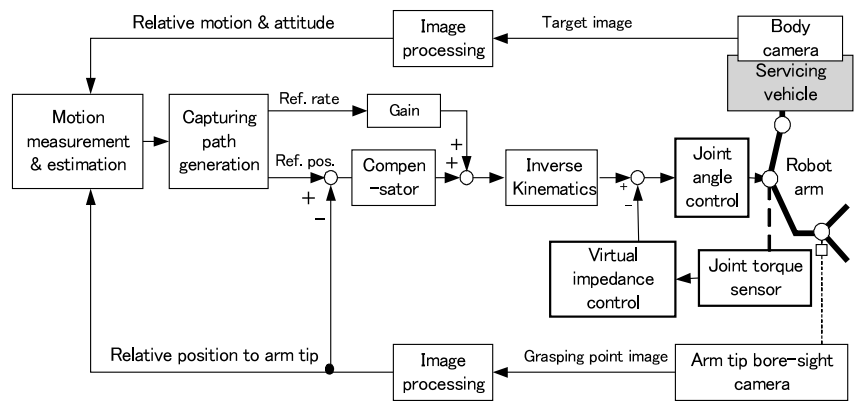

第 2 図 スペースデブリ捕獲アームの制御系統図

うことができる．このため，低い周波数帯に構造振動モ一 ドを有する形態となり，構造減衰も小さい，また，ペイロー ドの有無と質量やアーム姿勢により振動モード形状や固有 振動数が大きく変化する.方式 aでは, これらの構造共振が アームの関節アクチュエータとセンサの間に介在する．方 式bでは, センサとアクチュエータのコロケーションが成 り立つため，構造柔軟性にかかわらず高い応答性を得るこ とができる．また，運動物体の捕獲作業での力覚制御は, 動 的な荷重に対して高い応答性で反応せねばならないが, 方 式 bが適しているため，ここでは方式 b を選定した .

4.2 捕獲作業への力覚制御適用戦略 捕獲作業におい ては, 追従誤差による把持部の衝突やジャイロトルク, 柔 軟付属物による詳細な予測が困難な動的荷重の発生か想定 されるため, ロボットアームに緩衝機能が必要である. ま た，捕獲後には慣性運動する対象と作業機の運動速度/角速 度の差を無くすため, ロボットアームからのカ・トルク印 加により制動する必要がある，乥こで，アームによる捕獲・ 制動作業に次のように力覚制御を適用する。

・捕獲時 : 関節仮想インピーダンス制御による緩衝 ・制動時 : 関節仮想デプス制御（新規方式）による制動

4.3 関節仮想インピーダンス制御 関節トルクセンサ の情報をフィードバックしてインピーダンス制御10) や関節 トルク制御11) の一種である関節単位の仮想インピーダン ス制御系により，アームのインピーダンス制御を実現する アーム先端に設定したい仮想岡性 $\boldsymbol{k}_{\mathrm{TIP}}(6 \times 6)$ から関節単 位の仮想捻り剛性 $\boldsymbol{k}_{\mathrm{JNT}}(6 \times 6)$ への变換式は次式で求め られる。

$$
\boldsymbol{k}_{\mathrm{JNT}}=\boldsymbol{J}^{\mathrm{T}} \boldsymbol{k}_{\mathrm{TIP}} \boldsymbol{J}
$$

ここで, $\boldsymbol{J}(6 \times 6)$ は関節系からアーム先端系へのヤコビ行 列である .しかし，関節仮想インピーダンス制御において は , 式 (1) で得られた関節仮想捻り剛性行列の対角項のみ を使用することになり，この関節捻り剛性により実現でき るアーム先端岡性は, 非対角項を無視したことにより，手 首関節から仮想コンプライアンス中心までの長さが長い場 合に特に先端での回転剛性が過大となる傾向を生じる．し かし, 単に衝撃の緩衝を目的とした捕獲作業での関節仮想 インピーダンス制御の適用では, アーム先端の仮想剛性の 異方性は問題にならない，乥こで，手首の長さによるアー 么先端並進岡性の低下や非等方化を許容して, 手首関節の
仮想捻り剛性を目標とする先端の回転剛性と同等のレベル に設定し，肩・肘の 3 関節は手先の並進岡性と基部からの 距離を考慮した均一の捻り剛性に設定する。

関節の角度制御目標 $\theta_{R E F i}$ は次の式で与えられる。

$$
\begin{aligned}
& \theta_{\mathrm{D} i}=\frac{1}{I_{i}} \int_{t_{0}}^{t} \int_{\mathrm{REF} i}\left(\tau_{i}-c_{i} \dot{\theta}_{i}-k_{\mathrm{JNT} i} \theta_{i}\right) \mathrm{d} t^{\prime} \mathrm{d} t \\
& \theta_{\mathrm{COM} i}-\theta_{\mathrm{D} i}
\end{aligned}
$$

ここで，

$I_{i}:$ 仮想慣性モーメント

$\tau_{i}:$ 関節トルク (トルクセンサ検出値)

$c_{i}:$ 仮想粘性係数

$\dot{\theta}_{i}:$ 関節の回転速度

$\theta_{i}:$ 関節の角度

$\theta_{\mathrm{COM} i}:$ 関節への角度指令值

$\theta_{\mathrm{D} i}$ は関節仮想インピーダンス制御による仮想变位に相当 する量であり，静的には関節の出カトルクにほぼ比例した 量となる.これを関節コンプライアンス補正量と呼ぶ .

関節の負荷トルクにより，実際の関節角度 $\theta_{i}$, 角度制御 目標 $\theta_{\mathrm{REF} i}$ およひ関節のモータ軸センサ情報から求めた関 節角度 $\theta_{\mathrm{ES} i}$ の間には，関節より負荷側の構造，機構の弾性 変形 $\varepsilon_{\mathrm{E} i}$ や角度制御偏差 $\varepsilon_{\mathrm{S} i}$ が介在している.これらの関 係は次式となる 。

$$
\theta_{i}=\theta_{\mathrm{ES} i}-\varepsilon_{\mathrm{E} i}=\theta_{\mathrm{REF} i}-\varepsilon_{\mathrm{S} i}-\varepsilon_{\mathrm{E} i}
$$

式 (2)のラプラス変換・移項により次式を得る .

$$
\theta_{\mathrm{D}}(s)=\tau_{\mathrm{CC}}(s) /\left(I_{i} s^{2}+c_{i} s+k_{\mathrm{JNT} i}\right)
$$

これは 2 次のディジタルフィルタに変換される . また , 卜 ルクセンサ信号はノイズと高次機械共振のピークの影響を 抑えるためにローパスフィルタ回路を介してコントローラ に取り込む．また，速度リミッタにより対象との衝突時の 衝撃に対する過乘な反応を抑える。

4.4 関節仮想デプス制御 関節仮想インピーダンス制 御の有する高応答性での衝撃緩和機能に加えて, 捕獲対象 に対してロボットアームから積極的に力を印加して運動の 制動を行う関節仮想デプス制御を新規に考案した . 以下に 乥の内容を示す。

4.4.1 減速制動プロファイル 減速プロファイルを設定 し，光の減速に想定される制動力を加えることによりター ゲットからの角運動量の移譲をスムーズに受けることを目 指す．ターゲットの回転運動に対して，把持点が手前側にあ る間に制動せねばならないため, 必要な制動加速度が決ま る.例えば，捕獲後にターゲット (回転角速度: $\omega_{0}$ ) が 60 度 回転内て制動するための一定の制動角加速度は, $1.5 \omega_{0}^{2} / \pi$ となる

一般にターゲットの質量特性や太陽電池パドルなどの柔 軟付属物の特性は不明であるため, 捕獲時の接線速度とアー ムから印加可能な制動力を基に減速プロファイルを設定す る.制動力を台形状に变化させ , 印加可能な制動力の範囲 
で制動し，アームの速度が一定レベル以下に低下した後に 徐々に制動力を下げることにより，滑らかな制動を行う。

4.4.2 制動動作制御方式 制動力を発生する制御方法と して , 関節仮想インピーダンス制御に加えて関節ごとに仮 想的な食い込み量の目標值を設定することにより関節トル クを制御する関節仮想デプス制御を新規に構成した .これ により，関節仮想インピーダンス制御による緩衝機能と安 定性, 制動力の印加を両立させた捕獲・制動動作を行う。

時々刻々に各関節で発生すべきトルク $\boldsymbol{\tau}_{\mathrm{REF}}(t)$ は,アー ム先端での目標制動力 $\boldsymbol{F}_{\mathrm{D}}(t)$ から次式で与えられる .

$$
\boldsymbol{\tau}_{\mathrm{REF}}(t)=\boldsymbol{J}^{\mathrm{T}} \boldsymbol{F}_{\mathrm{D}}(t)
$$

関節 $i$ においては, 仮想インピーダンス岡性 $k_{\mathrm{JNT} i}$ に応じ て, 次式により仮想的な食い込み目標角 $\theta_{\mathrm{B} i}(t)$ を設定する。

$$
\theta_{\mathrm{B} i}(t)=\tau_{\mathrm{REF} i}(t) / k_{\mathrm{JNT} i}
$$

これを目標としつつ関節仮想インピーダンス制御演算を行 うことにより，現在の目標関節角度 $\theta_{\mathrm{COM} i}$ に対して食い 込み目標角だけ関節の仮想インピーダンス中心角 $\theta_{\mathrm{CC} i}$ が 食い込んだ状態に制御され，制動卜ルクを発生することが できる.従って, 関節角度制御の制御目標角 $\theta_{\mathrm{REF} i}$ は, 次 式で表される .

$$
\theta_{\mathrm{REF} i}=\theta_{\mathrm{COM} i}-\theta_{\mathrm{D} i}+\theta_{\mathrm{B} i}
$$

これらの角度量と現在の関節角度 $\theta_{i}$ との関係を第 3 図に

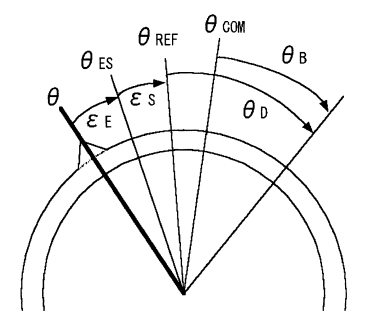

第 3 図 関節角度と関節仮想デプスの関係
示す．また，各関節の関節仮想デプス制御系のブロック図 を第 4 図に示す . 2 つのスイッチの on/offにより，関節角 度制御，関節仮想インピーダンス制御，関節仮想デプス制 御を容易に切り換えることができる．

\section{5. 捕獲動力学シミュレーション}

前節で設定した捕獲制御戦略に沿った捕獲時の制動制御 について衛星本体や関節の弾性 ${ }^{12)}$, 摩擦特性なども含めた 詳細なモデルによる 3 次元動力学シミュレーションを実施 し，制動時の動作や発生荷重を調べた。

5.1 シミュレーションモデル 作業機に搭載したロボッ トアームによりターゲットを捕獲する場合を想定し，作業 機本体の 6 自由度剛体, 太陽電池パドル，ロボットアーム および 6 自由度剛体のターゲットを考慮した 3 次元モデル を構成する．想定するモデルの構成を第 5 图に示す．

作業機本体と太陽電池パドルの柔軟性を考慮すると，作 業機の運動方程式は，次式で表される .

$$
\boldsymbol{M}_{\mathrm{B}} \ddot{\boldsymbol{\varphi}}_{\mathrm{B}}+\boldsymbol{C}_{\mathrm{B}} \dot{\boldsymbol{\varphi}}_{\mathrm{B}}+\boldsymbol{K}_{\mathrm{B}} \boldsymbol{\varphi}_{\mathrm{B}}=\boldsymbol{f}_{\mathrm{D}}+\boldsymbol{f}_{\mathrm{C}}+\boldsymbol{\Phi}_{\mathrm{B}}^{\mathrm{T}} \boldsymbol{f}_{\mathrm{A}}
$$

ここで， $\varphi_{\mathrm{B}}$ は衛星本体の構成自由度であり， $M_{\mathrm{B}}, C_{\mathrm{B}}$, $\boldsymbol{K}_{\mathrm{B}}$ は, 各々これに対応した衛星本体の慣性行列, 粘性行 列，剛性行列である．また， $f_{\mathrm{D}}$ は衛星本体への姿勢外乱 トルク, $f_{\mathrm{C}}$ は衛星姿勢制御トルク,$f_{\mathrm{A}}$ はアーム基部から 衛星本体に加わる力/トルク， $\Phi_{\mathrm{B}}$ はアーム基部から衛星本 体質量中心への剛体変位係数行列である.太陽電池パドル

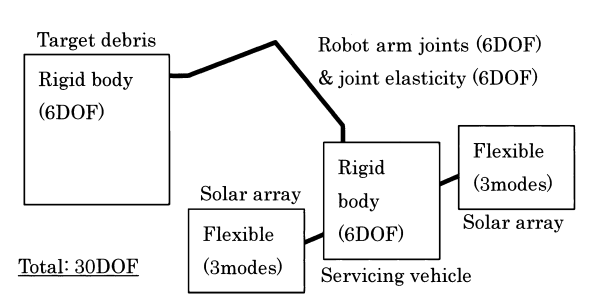

第5图 動力学解析モデルの構成

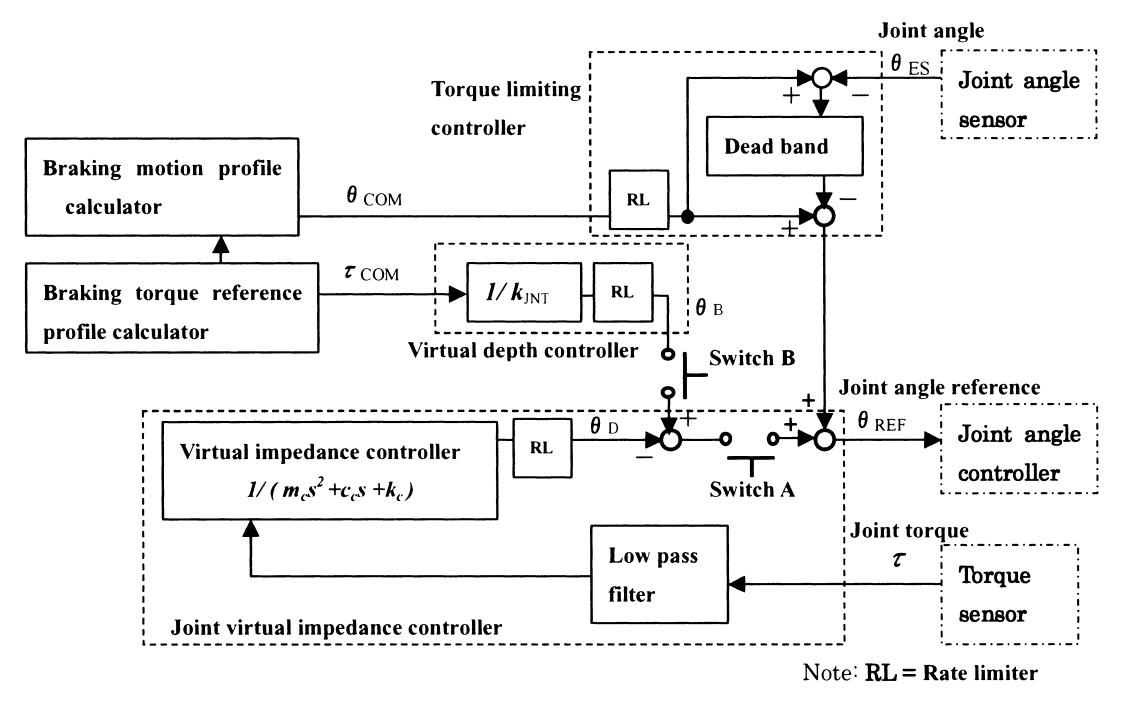

第4図 関節仮想デプス制御系ブロック图 


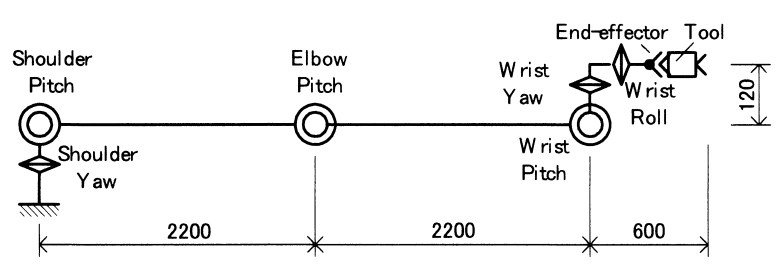

第 6 図 解析で想定したロボットアーム自由度配置

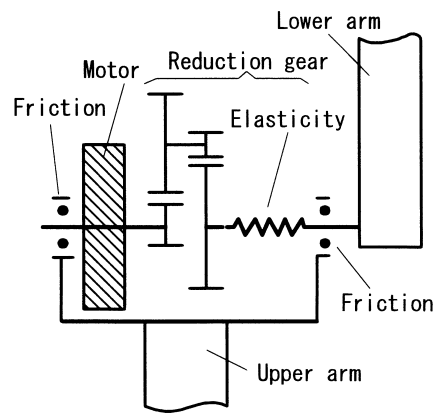

第 7 図＼cjkstart関節のシミュレーションモデル構成

は, 対称の両翼タイプとし, 片翼あたり 3 自由度の柔軟構 造特性を考慮したモデルとした。

アームのモデルは , 次式で表すことができる .

$$
\boldsymbol{M}_{\mathrm{A}} \ddot{\boldsymbol{x}}+C_{\mathrm{A}} \dot{\boldsymbol{x}}+K_{\mathrm{A}} \boldsymbol{x}=\boldsymbol{\tau}-\boldsymbol{J}_{\mathrm{A}}^{\mathrm{T}}\left(\boldsymbol{f}_{\mathrm{TIP}}+\boldsymbol{f}_{\mathrm{A}}\right)
$$

ここで, $M_{\mathrm{A}}, C_{\mathrm{A}}, K_{\mathrm{A}}$ は各々アームの慣性, 粘性係数, 岡性のマトリクス, $x$ はアームの関節変数, $\tau$ は関節出力 トルク, $\boldsymbol{f}_{\mathrm{TIP}}$ はアームに先端から加わる荷重, $\boldsymbol{J}_{\mathrm{A}}$ はアー ムの関節からアーム先端系へのヤコビ行列である . ロボッ トアームは, 第 6 図に示した 6 自由度アームをモデル化し た 、ロボットアームの関節については，次式のモデルとし， 減速機弾性 , バックラッシュ, モータ軸と関節出力軸（回 転角度 : $\theta_{i}$ ) の摩擦 (静止摩擦, クーロン摩擦, 粘性摩擦) をモデル化した (第 7 図).

$$
\begin{aligned}
& \quad I_{m i} \cdot \ddot{\theta}_{m i}+d_{m v} \cdot \dot{\theta}_{m i}+d_{m c} \cdot \dot{\theta}_{m i} /\left|\dot{\theta}_{m i}\right| \\
& \quad=\tau_{m i}-k_{\mathrm{RG}}\left(\varepsilon_{i}\right) \cdot \varepsilon_{i} / n \\
& \tau_{i}+d_{v} \cdot \dot{\theta}_{i}+d_{c} \cdot \dot{\theta}_{i} /\left|\dot{\theta}_{i}\right|=k_{\mathrm{RG}}\left(\varepsilon_{i}\right) \cdot \varepsilon_{i} \\
& \varepsilon_{i}=\theta_{m i} / n-\theta_{i} \\
& \text { ここで, }
\end{aligned}
$$

$I_{m i}:$ モ一夕軸部慣性

$\theta_{m i}:$ モ一夕軸回転角度

$d_{m v}, d_{v}$ : モ一タ軸, 関節出力軸の粘性摩擦係数

$d_{m c}, d_{c}:$ モ一タ軸, 関節出力軸のクーロン摩擦

$\tau_{m i}:$ モータ出力トルク

\begin{tabular}{|c|c|c|c|}
\hline Items & Values & Items & Values \\
\hline $\begin{array}{l}\text { Joint mass } \\
\text { Boom mass }\end{array}$ & $\begin{array}{l}3.5 \mathrm{~kg} \\
8 \mathrm{~kg}\end{array}$ & Capture ha & $\begin{array}{l}3000 \mathrm{~N} / \mathrm{m}, \\
300 \mathrm{Nm}\end{array}$ \\
\hline $\begin{array}{l}\text { Servicing } \\
\text { vehicle } \\
\text { inertia }\end{array}$ & $\begin{array}{l}1000 \mathrm{~kg}, \\
1000 \mathrm{kgm}^{2}\end{array}$ & $\begin{array}{l}\text { Capture hand damper } \\
\text { Capture hand mass }\end{array}$ & $\begin{array}{l}208 \mathrm{Ns} / \mathrm{m}, \\
247 \mathrm{Nms} \\
9.5 \mathrm{~kg}\end{array}$ \\
\hline $\begin{array}{l}\text { Arm inertia } \\
\text { Solar array }\end{array}$ & $\begin{array}{l}408 \mathrm{kgm}^{2} \\
53 \mathrm{~kg}\end{array}$ & $\begin{array}{l}\text { Joint output viscosity } \\
\text { of gear and bearing }\end{array}$ & $20 \mathrm{Ns} / \mathrm{m}$ \\
\hline $\begin{array}{l}\text { Cantilever } \\
\text { frequency of } \\
\text { solar array }\end{array}$ & $\begin{array}{l}0.2 \mathrm{~Hz} \\
0.6 \mathrm{~Hz} \\
1.0 \mathrm{~Hz}\end{array}$ & $\begin{array}{l}\text { Joint elasticity } \\
\text { Torque sensor cutoff } \\
\text { frequency }\end{array}$ & $\begin{array}{l}25000 \mathrm{Nm} \\
64 \mathrm{~Hz}\end{array}$ \\
\hline
\end{tabular}

$\tau_{i}:$ 関節出力トルク

$k_{\mathrm{RG}}(\varepsilon):$ 減速機捻り岡性特性

$n:$ 減速比

なお, 静止摩擦は, 回転速度の判定と式 (11), 式 (12) の右
第 2 表 シミュレーションに使用したパラメータ

辺と静止摩擦トルクの大小の判定により模擬する .

ターゲットは, 剛体と見なした。従って, 運動方程式は， 次式で表される .

$$
\boldsymbol{M}_{\mathrm{T}} \ddot{\boldsymbol{\varphi}}=\boldsymbol{\Phi}_{\mathrm{AT}}^{\mathrm{T}} \boldsymbol{f}_{\mathrm{TIP}}
$$

ここで， $M_{\mathrm{T}}$ はターゲットの慣性マトリクス， $\varphi$ はター ゲットの剛体自由度, $\boldsymbol{f}_{\mathrm{TIP}}$ はアームにより把持点から加 わった荷重， $\Phi_{\mathrm{AT}}$ はターゲット質量中心からアーム先端へ の岡体変位係数行列である.

ターゲットの捕獲時に画像フィードバック制御によるアー 么の捕獲部位追従速度に誤差のある場合，把持時に衝突に よる衝撃荷重を生じる．先に述べたように捕獲部位は，衝 撃緩和のための弾性部材を有するため, モデル上でも 6 自 由度のバネ・ダンパでの模擬とする .

なお，解析はニュートンオイラー法を用い，積分手法に はルンゲ・クッタ・ギル法を使用し，1 1 ミリ秒の積分刻み で実施した。

5.2 シミュレーションモデルパラメータ 解析に使用し た主要なパラメータを第 2 表に示す .

5.3 シミュレーションケース

5.3.1 初期条件 回転するターゲットの捕獲対象部を口 ボットアームで追従・捕獲した後に減速制動する場合を想 定した，想定した配置，捕獲位置などを第 8 图に示す。作 業機の姿勢制御はオフとし, 自然外乱トルク/外乱力を無視 した．また，画像フィードバック制御等による追従動作に 速度誤差が無いものとし，捕獲時の残留力が無いケースに つきシミュレーションを行った .ここで, ターゲットの回 転速度は， $1 \mathrm{deg} /$ 秒とした .アームの追従運動動作および 減速動作は両衛星の重心・捕獲部位のある同一平面内に設 定した。

5.3.2 の他の条件目標制動カプロファイルは， $0.5 \mathrm{Nm} / \mathrm{s}$ の回転速度減速分の $\mathrm{S}$ 字トルク加減プロファイ ルで, 一定制動卜ルクを $4 \mathrm{Nm}$ に設定した . ターゲットの 詳細な質量特性は不明だが対象の大きさと打上時のデータ により概算値のみが既知という前提で概算値を基に(誤 差 : 約 6\%) ターゲット回転の減速加速度を算出し，これ を積分した值を目標制動動作プロファイルとして各解析 ケースのアーム制御に使用した 。

5.4 制御方式 ターゲットをロボットアームにより追従 する速度に対して減速プロファイルを設定し, 次の 3 種類 


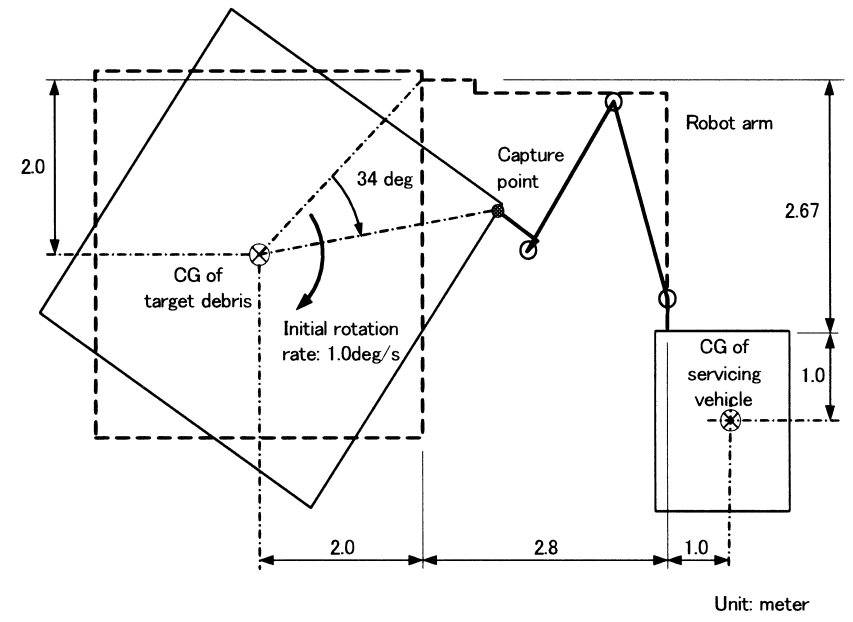

第 8 図 解析ケースでの配置

の制御方式で捕獲・減速時の発生荷重を解析・比較するこ とにより，考案した制御方式の有効性を調べた .

a. 位置制御 : 減速プロファイルに基づいた位置制御

b. 関節仮想インピーダンス制御 : 位置制御に関節仮想イン ピーダンス制御を付加

c. 関節仮想デプス制御：位置制御に関節仮想デプス制御を 付加

5.5 シミュレーション結果, 考察 各制御方式を用いた シミュレーション結果を第 9 図に示す . 位置制御の場合に は , a に示すようにプロファイルのずれが大きくなる後半 (20 秒後付近， 60 秒後付近) に荷重が大きくなり，関節仮 想インピーダンス制御の場合には，bに示すように関節仮 想インピーダンス制御が減速プロファイルによる制動力の 発生を抑えるように機能してしまうため，十分な制動が行 われず，後半にずれが大きくなり荷重の発生か続く結果と なっている，一方，関節仮想デプス制御の場合には，cに 示すように変動しつつもほぼ期待するプロファイルで制動 力が発生し, 十分な減速が行われ, 制動後の残留振動も小 さい，また，関節仮想インピーダンス制御では，荷重緩和 のための逃げ動作を生じるため, 所期の動作プロファイル から大きくはずれた動作となる .これにより，デブリ捕獲 時の制動動作において関節仮想デプス制御は位置制御や関 節インピーダンス制御よりも滑らかで所期の制動動作が得 られることが確認できたと考えられる .

$$
\text { 6. 実験 }
$$

\section{1 実験方法}

6.1 .1 想定ケース 作業機によるターゲットの捕獲・制 動については，最終的には質量の軽い作業機側がターゲッ トと一体となって回転する動作と見なすことができる .こ の動作は，ターゲット上から見れば，基部を固定したロボッ トアームで作業機の並進運動に近い円弧運動を加速したり， 制動する作業と同等と見なすことができる．

6.1 .2 実験装置と設定 基部固定の 2 次元ロボットアー ムを用いて関節仮想デプス制御方式による制動動作の効果

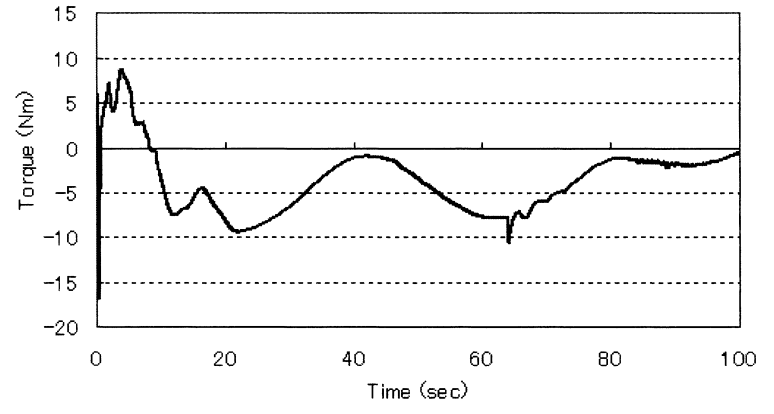

a. 関節角度制御のみの制動

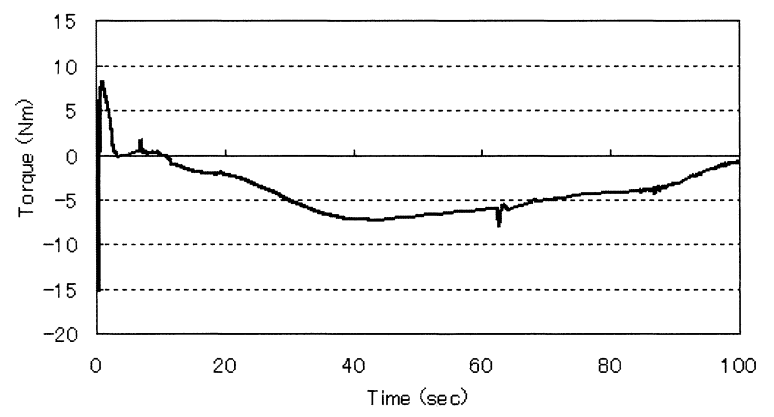

b. 関節仮想インピーダンス制御による制動

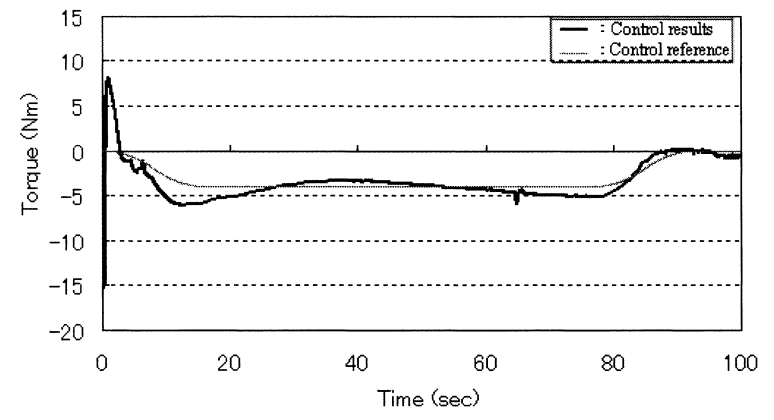

c. 関節仮想デプス制御による制動と目標制動トルク

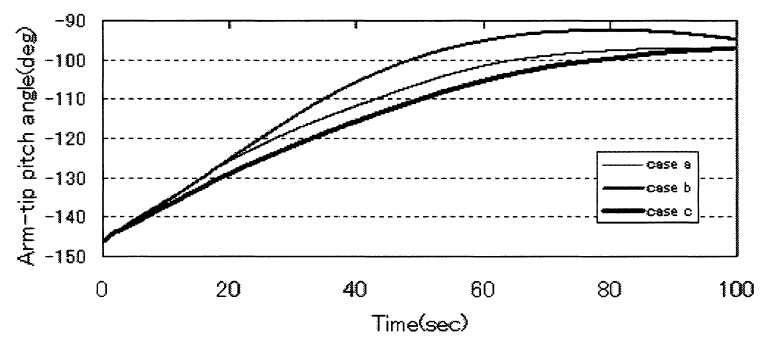

d. 各ケースのアーム先端ピッチ姿勢角 (アーム基部基準)

第 9 図 3 次元動力学解析結果 (仮想インピーダンス中心ピッチ軸回 りモーメント等)

を確認する実験を実施した 、ロボットアーム (第 10 図) は， 4 関節の水平多関節アーム (関節アクチュエータ: ハーモ ニックドライブシステム社製 RH11D-3001, 出力軸部にト ルクセンサを組込，各リンク長は $0.2 \mathrm{~m})$ であるが , 今回の 実験では冗長自由度は必要ないため第 2 関節を角度ホール ド制御する 3 関節モードで使用した . 想定している搭載口 ボットアームの約 $1 / 10$ のスケールであるため，作業機を 想定した負荷質量も振動や応答周波数に関して想定ケース に整合させる観点に立てば $1 / 10$ (約 $70 \mathrm{~kg}$ ）とすることが 


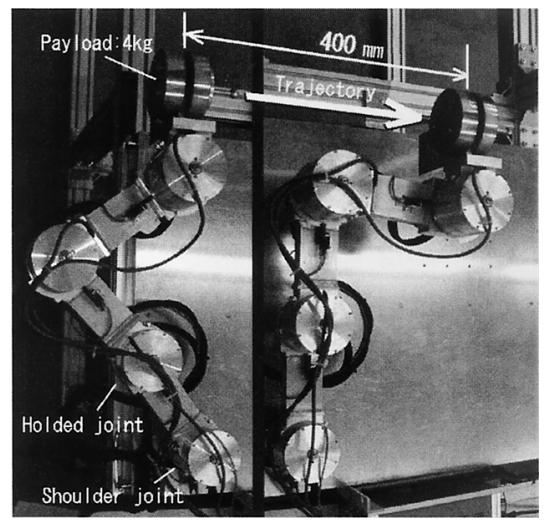

第 10 図 2 次元アーム実験装置と設定動作
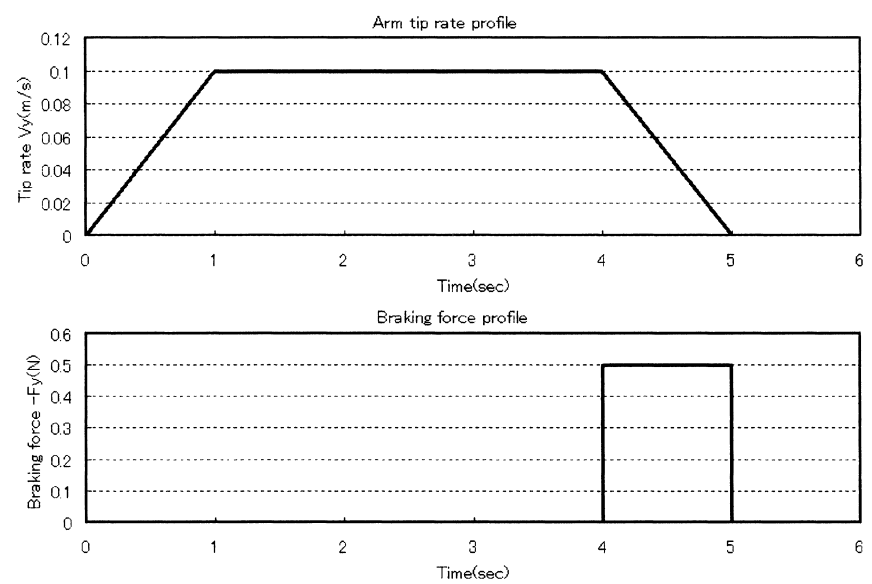

第 11 図 2 次元アーム実験の速度と目標制動力のプロファイル

望ましい . しかし , 片持ちのアーム実験装置において重力 による関節の倒れモーメント耐性の制約のため, 手先の慣 性負荷は $4 \mathrm{~kg}$ に抑えざるを得なかった . 従って , 想定ケー スよりも負荷慣性としては小さい，慣性力が支配的な制動 状況をできるだけ模擬するため，動作ストローク $400 \mathrm{~mm}$ の中で負荷の運動量を極力大きく設定すべく，最大速度： $100 \mathrm{~mm} / \mathrm{s}$ で直線動作させた .この動作の減速動作に対し て，位置制御，関節仮想インピーダンス制御，関節仮想デ プス制御の各制御方式での制動・停止動作の実験を行い，応 答を比較した .なお，加減速パターンには台形パターンを 用いた (第 11 図).関節仮想デプス制御では，減速中に先 端で $0.5 \mathrm{~N}$ の制動力を目標とした制御を行った .

6.1 .3 使用パラメータ 関節の仮想インピーダンス特性 は , 以下に示すアーム先端の仮想インピーダンス特性につ いて時々刻々に式 (1) で求めた関節岡性マトリクスの対角 項を算出して用いた。

$$
\begin{aligned}
& \left\{m_{x}, m_{y}, I_{\theta}\right\}=\{4.0,4.0,0.2\} \\
& \left\{c_{x}, c_{y}, c_{\theta}\right\}=\{171,171,8.6\} \\
& \left\{k_{x}, k_{y}, k_{\theta}\right\}=\{1826,1826,91\}
\end{aligned}
$$

粘性については, 先端について臨界減衰となるように設定 し, 同樣の算出方式により関節の仮想粘性マトリクスを求

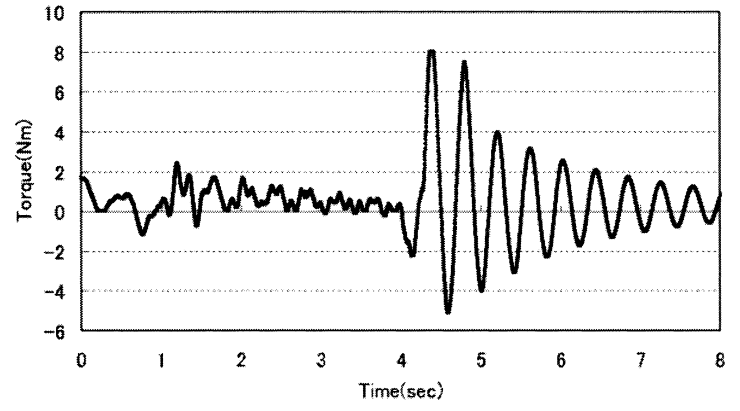

a. 位置制御での制動

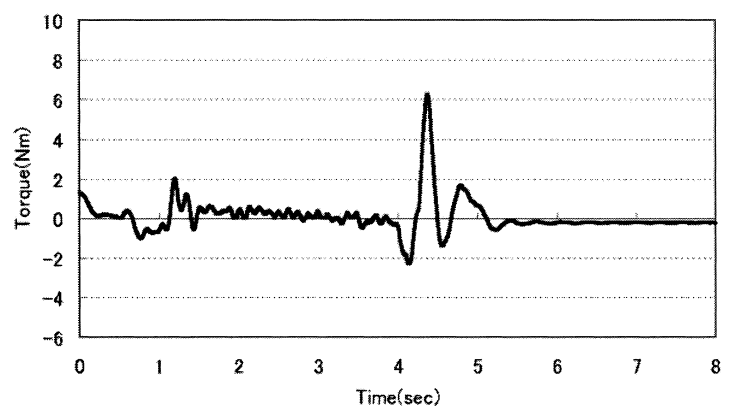

b. 関節仮想インピーダンス制御での制動

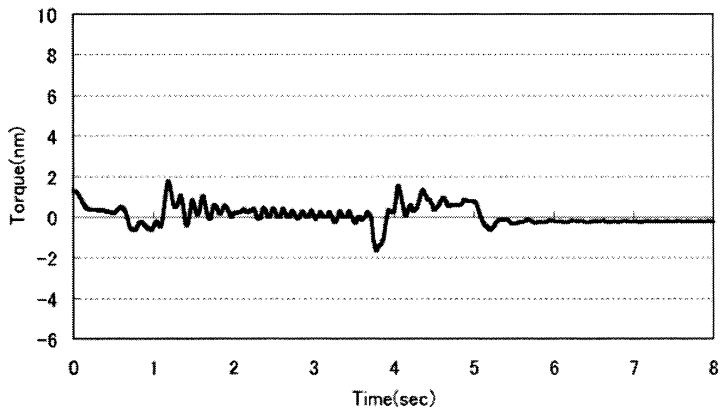

c. 関節仮想デプス制御での制動

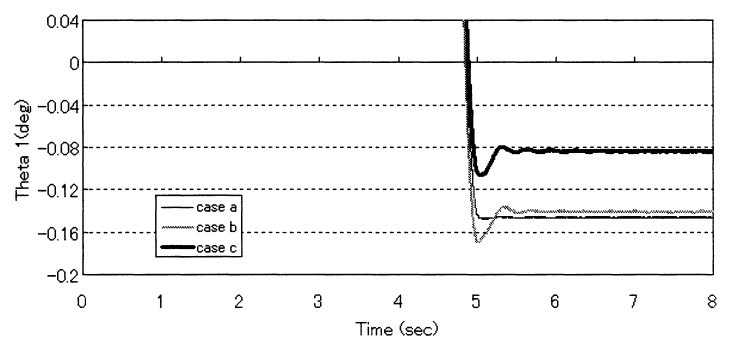

d. 各ケースでの第一関節角度の履歴

第 12 图 2 次元アーム制動実験結果 (肩関節卜ルク・角度履歴)

めた．また，仮想回転慣性については先端負荷を $4 \mathrm{~kg}$ の質 点と想定して, 関節ごとに時々刻々算出した。

6.2 実験結果, 考察 各制御方式での発生荷重を代表 する值として肩の第一関節のトルク履歴を第 12 図に示す． 位置制御では，a に示すように定速動作からの減速開始と 同時に振動的な荷重を生じ，停止後も小さな減衰のまま振 動が残留している . 振動は, アームの関節機構の柔軟性に 主に依存する構造の一次固有振動である，一方，関節仮想 インピーダンス制御を適用したケースでは，bに示すよう に aよりは振動の減衰が大きいが, 少なからぬ振動が生じ 
ており，関節角度のオーバシュートも大きい，乥して，関 節仮想デプス制御では， c に示すように振動の発生も少な く，所期の制動力が発生されている．また，滑らかな制動 動作により停止していることが第一関節角度の履歴からも 読みとられる．これにより，関節仮想デプス制御では，対 象に対して設定した制動力プロファイルに忠実な制動力/卜 ルクの印加が行え, 過大力の発生や振動, オーバシュート も小さいことか確認できた .これにより, 軌道上で想定す るケースに対して約 $1 / 18$ の軽負荷慣性のケースについて， 関節仮想デプス制御により所期の制動特性が得られ，関節 角度制御や関節仮想インピーダンス制御のみを適用した場 合に比較して良好な制動特性が得られることか確認できた . (これ以上の負荷慣性の場合については, より大掛かりな実 験装置の対象となる .)

$$
\text { 7. おわりに }
$$

低速回転するスペースデブリのロボットアームによる捕 獲作業を検討し，捕獲/制動時の荷重㗔衝と制動力の印加を 高い応答性で実現する力覚制御手法である関節仮想デプス 制御を提案し, 詳細な 3 次元動力学シミュレーションによ り提案した制御方式の制動動作への有効性を確認した .ま た，2 次元ロボットアーム実験装置を用いて，提案した制 御方式の制動動作への有効性を軽負荷の対象について実験 によっても確認した .

動力学シミュレーションに当たっては, NT スペースの 林 正人氏，菅野 崇氏に多大なご協力を頂いた．この場
を借りて感謝の意を表する

$$
\text { 参 考 文 献 }
$$

1) 西田信一郎, 吉川恒夫, 菅野 崇: 力覚制御アームによる衛星捕 獲, 誘導制御シンポジウム, 2002.

2) 西田信一郎, 照井冬人, 河本聡美 : デブリ除去技術へのアプロー チ, 計測と制御 , 41 (2002), pp. 575-580.

3) 稲場典康, 小田光茂, 西田信一郎, 林 正人 : 宇宙ロボットによ る浮遊衛星捕獲のシステム設計, 日本航空宇宙学会論文集, 51 (2003), pp. 469-474.

4) Oda, M., Nishida, S., Inaba, N., Hayashi, M., Takano, Y. and Sugano, T.: Onboard Local Compensation on ETS-VII Space Robot Teleoperation, Proc. of AIM '99, Atlanta, 1999.

5) Nishida, S., Toriu, H. and Hayashi, M.: Robot Arm System for Automatic Satellite Capture and Berthing, Proc. of i-SAIRAS '94, 1994.

6) 西田信一郎, 吉川恒夫 : 宇宙ロボット用トルクセンサ内蔵関節の 試作, 第 20 回日本ロボット学会学術講演会予稿集, 2002.

7) 西田信一郎, 吉川恒夫 : 宇宙用アクティブリンプロボット関節の 開発，日本航空宇宙学会論文集， 52 (2004), pp. 393-401.

8）小松督, 植之原道宏, 飯倉省一, 三浦宏文, 下山 勲: トルク フィードバックを用いた宇宙用多リンク柔軟マニピュレータの振 動制御, 日本ロボット学会誌, 8 (1990), pp. 39-46.

9) Kawamoto, S., Matsumoto, K. and Wakabayashi, S.: Ground Experiment of Mechanical Impulse Method of Uncontrollable Satellite Capturing, i-SAIRAS2001, 2001.

10) Mason, M. T.: Compliance and Force Control for Computer Controlled Manipulators, IEEE Trans. System, Man Cybernetics, SMC-11 (1981), pp. 418-432.

11) Luh, J. Y. S., Fisher, W. D. and Paul, R.: Joint Torque Control by a Direct Feedback for Industrial Robot, IEEE Trans. Automatic Control, AC-28 (1983), pp. 153-160.

12) Shiraki, K., Kubo, T. and Nishida, S.: Simulation for Developing JEM Remote Manipulator, Proc. of i-SAIRAS '92, 1992. 